\title{
THE SEA, THE VOLCANO AND THE TIGER: SOME ANIMISTIC SYMBOLS IN ORAL TRADITION AND MODERN INDONESIAN LITERATURE
}

\author{
Marina Frolova \\ Institute of Asian and African Studies \\ Moscow State University \\ m.v.frolova@gmail.com \\ DOI: https://doi.org/10.24071/ijhs.2017.010103 \\ received 5 March 2016; revised 21 February 2017; accepted 7 July 2017
}

\begin{abstract}
The article deals with the idea of rediscovering three basic images of Indonesian culture: the sea, the volcano and the tiger, with the help of folklore and splendid literary works of modern Indonesian writers as well. Novels by Mochtar Lubis (Harimau! Harimau! 1975), Eka Kurniawan (Lelaki Harimau, 2004), and Budi Sardjono (Sang Nyai, 2011) are taken as a source. The enriched traditional meanings of some animistic symbols appear in different light in each novel, rediscovering the layers of main plot and characters connotations in different ways of Neo-Traditionalism, Deconstruction and Remythologization.
\end{abstract}

Keywords: animistic symbols, Malay and Javanese basic archetypes and tradition, modern Indonesian literature.

\section{Introduction}

The significant role of the mighty animistic patterns in Malay and Indonesian culture is written enough. A number of great scholars and explorers of Nusantara made ethnographical and anthropological studies about shamanism and widespread belief in spirits and ghosts. Studying the rituals and the everyday life oddities for the Western eye, R. Wessing, R.E. Jordan, N. Mulder, J.J. Ras, W.W. Skeat, K.M. Endicott and many others viewed closely upon rudimental images of ancient animism of Malay Archipelago. However, quite a small amount of scientists paid enough attention to the folklore and literature precisely focusing on its sources. Exceptions were made by specialists in Malay and Indonesian literature. W. Rassers, T.G.T. Pigeaud, B. Parnickel and V. Braginsky achieved important results in reconstructing the system of regional animistic images, which root into the undiscovered past of the Indonesian islands. For example, due to their works we can also comprehend the role of the ship image in Malay tradition and the powerful clown-figures (punokawan) of the Javanese shadow plays in theatre, oral tradition and its transformations in the modern Indonesian literature. With the developing of literature studies in Nusantara, we can continue to fill in the information gap about other images and signs, which mark the whole Indonesian culture and represent the mindset of the native people. 
The article deals with the idea of rediscover three images of Indonesian culture: the sea, the volcano and the tiger, with the help of folklore and splendid literary works of modern Indonesian writers as well. Novels by Mochtar Lubis (Harimau! Harimau!), Eka Kurniawan (Lelaki Harimau), and Budi Sardjono (Sang Nyai) are taken as a source. The objects of the present paper are the symbolical models of ancient beliefs of Indonesians, which are "pulled up" from the original literature. The subject deals with cultural particularities of animistic symbols, their enrichment through the influence of the other cultures.

\section{Theory}

\section{The Archaic and the Tradition}

Pre-writing tradition of Nusantara includes oral folktales (cerita rakyat), magic spells (mantra, guna-guna), shadow plays (wayang purwo). The original "literature of the tradition" covers the divine revelation of the shaman, recitation by heart of the scholar, puppet master's (dalang) improvisation of some slightly fixed texts like shadow theatre scenario (pakem). These conglomerate of mixed texts represent the gradual enrichment of the original content by the external influences, remarkably brought by Indian (VII-XIV centuries) and Middle Eastern (XIV-XIX centuries) Civilizations. From the linguistic perspective, two main court and high-literary languages have been used, Malay and Javanese (each in its old form). Information about animism is taken from the Malay texts because of the historical lingua franca role of Malay language as a mediator; some of the examples are taken from Malay translations of original Javanese texts (cerita Panji), with its core in theatrical performances (wayang kulit).

Ancient myths, mirrored in shadow plays, folktales and first written literature, collect the images of the Universe. The main features of this picture are the following.

1) Axis mundi, the World axis, represented as World Mountain or a World Tree - we can witness this in special figure of wayang, gunungan of kayon, called so after "mountain" (gunung) and the "tree" (kayu). The "fire-mountain", of the Volcano, is the place of Sakti concentration, the magic power.

2) The journey to the land of the dead can be managed by the means of the special transport - the boat or the Ship, which plays the important role in everyday life of the Archipelago.

3) Crossing over the jungle Forest always means the struggle and the defeat of the wild Beast.

4) The helpful servants are always in the picture - several figures of the jests and clowns, who accompany the prince. Those figures, as proofed, also known as Punokawan, are the mighty spirits of the volcanoes and the hosts of the Java Island in disguise, the ancient fertility deities.

5) The Semangat substance and the ability of some chosen ones (dukun) to turn into the animals and nature objects, and the old and wide-spread belief into the Were-tigers, based on the semangat concept and the mutual Isomorphism of "inanimate" objects, animals and men. 
6) The cult of the Great Goddess, in her most ultimate aspects of Batari Durga, the female Ruler of Destruction and Death, and the famous Nyai Roro Kidul, the Queen of the Southern Sea.

These patterns formed inseparable with Hinduism and Buddhism, which did not eliminate the strong animistic basic and the beliefs in ghosts and evil spirits, and the divinization of the natural objects. But the Islamization brought new perspective for these powerful images. Preserving the old meanings of them, such as defeating the beast meant the initiation of the hero, Sufi tradition from the Middle East added the other significant meaning. The defeated beast begins to mean the defeated wreath in the ones heart, nafsu ammarah.

\section{The Modernity}

In our opinion, the segment of the recognized modern Indonesian literature before the Independence (the Balai Pustaka and the Pujangga Baru generations) cannot provide the sufficient base of archaic symbols due to its turn to the Western narrative strategies and its explore of the Western styles of the literature. The rich experiments of early Indonesian writers and poets, however, can ensure the great themes of other cultural studies. We cannot deny also the fact, that young Indonesian literature moved on very fast, and absorbed different modern features of the world's literature after 1945. The "Great come back" to the search of the national roots occurred in late 1960es - 1970es and the fascinating process of Neo-Traditionalism lasts till now (Braginsky, 2001). The ancient myths, traditional images and well-known plots re-actualize in "big literature", in highleveled novels created by the most recognized national Indonesian writers. Their works open good opportunities of interpretation of the traditional symbols in the contemporary literature.

\section{Theory Application}

\section{The traditional were-tiger and the modern deconstruction of the Sufi Path}

The novel Tiger! Tiger! (Harimau! Harimau! 1975) By Mochtar Lubis (1922-2004) is built on the plot-forming symbol of the tiger. The novel was published in the mid-seventies, and we will not reflect about its content in here much, because of numerous studies about this masterpiece of new Indonesian literature. Just one remark - the young hero Buyung managed to defeat the beast and to kill "the tiger in his heart", as a couple of times reminded to the reader. Here lies the idea of the traditional literature - the defeat of the nafsu ammara, the Sufi concept of the animal nature of the human beings, the dark side of their souls, and the destructive chaos. The multifaceted character of the tiger also represents the Allah's wreath and the divine vengeance for the sinners, due to the main solid Islamic discourse of the novel.

The contemporary writer Eka Kurniawan (born in 1975) gives different perspective on the tiger image. His second novel Man Tiger (Lelaki Harimau 2004) is a postmodern 'penny dreadful' mockery, picked up from cerita horror and cerita hantu of mass-market, inspired by productive horror-novelist of the Soeharto Era, Abdulla Harahap. Eka Kurniawan manages to combine and remix the Indonesian 'pulp fiction' full of murder, erotic and mystic, cheap comics and their much more serious origin - the Nusantara folktales about were-tigers. The family background of the main character, young anti-hero Margio, recalls the 
social realism style, in the spirit of hopeless reality of the poor as displayed in plays and novels by prominent Soviet writer, Maxim Gorky. The gloomy backlight and the dense narrative reveal the unpleasant scenes of provincial life as the grotesque. Expressive Franz Kafka-motives are about to break in. The shamanic gift, inherited from the grandfather, gives Margio the power of supernatural power possession. Not alike the young Buyung character from Mochtar Lubis novel, Margio surrenders to the chaotic power and commits a crime, scene of which show up in the first chapter: "Its not me. It's the tiger in me" (Kurniawan, 2004, p. 39), and the were-tiger materialized in Margio - in the last: "At the same moment the tiger came out of him. White as a swan" (Kurniawan, 2004, p.192).

The proof of the plot element about the magical shamanic bound of the grandson and the grandfather is caused by the less formal communication between them and is found in the works of anthropologists (Frazer, 1960, p.172). Grandfather talked a lot about genies of both sexes, but the most incredible story was about the tiger. "Many villagers have become friends with the tigers... they received a special gift, which has been passed from generation to generation... Far ancestors have forgotten who in the kin was the first to enter into relations with the tiger" (Kurniawan, 2004, p.47). Margio received the gift in the erotic dream, which means that the 'Kurniawan's tiger' shows up as ancestors' gift and refers to the mythological plot about the zoomorphic sex partner. Totemism gets humans closer to animals. Putative ignorance about the role of the father in the conception brings to the substitution of the human ancestor with spirits, which are more close to the natural power" (Levi-Strauss, 2008, p. 25). Female spirits, or celestial wives, usually interfere in the shaman's trance experience, accompanied with strong sexual emotions" (Eliade, 2014, pp.64-66).

Then the plot gets to the breaking of the level (according to Eliade). After the obtaining the shamanic gift Margio becomes bloodthirsty, turns to the wild beast, crossing over the worlds of the humans and of the spirits. Till now some societies believe that the mental decease can be caused by the possession of the evil spirits: in the realistic way the story of Margio can be understood as historia morbi of a village psychopath.

At the same time the description of the tiger-spirit is not threatening: it is big, white and transparent. The only person who sees it its Margio's sister, who is convinced the tiger came to save them from the harm. This image of Margio's tiger lies closer to the folklore rimau kramat, or the white tiger spirit-guard, which roamed the sacred places like tombs of the Sufi saints (Skeat, 1990, p.163).

The main core of the novel is made by the means of deconstruction, the complex method of collection and dismantling. Unlike the heroes of oral traditional cerita rakyat and its written "brothers" - fixed Malay texts in Arabic script called hikayat, unlike the Mochtar Lubis' Buyung, the Neo-Traditional hero, Eka Kurniawan's Margio did not pass the test of defeating his own wreath and passions. His "tiger" is stronger than his mind. The fall of the young hero resembles the modern and post-modern philosophical ideas of the chaotic rule of dark matters. To underline this, Eka Kurniawan uses dark red paint in the descriptions. According to tradition, like wayang, the red face of giants (raksasa) is a spot of wreath and reckless minds. 
In Sufi tradition, nafsu - or the animal soul of humans - can be displayed as images of strange beasts and visions like the mouse escaping from the throat (Schimmel, 2012, p. 121). The modification of nafsu - nafsu ammarah is ones angry soul, the image of it can be seen apart from the body.

Before the murder Margio experiences strange state of body and soul similar to shamanic trance, called lupa in Malay and Indonesian (lupa literary means "to forget"). The Sufi adepts were familiar with the conditions called fana' - the transition to revelation and annihilation in the Allah's realm.

The Path to this is commonly called tarikat. We can say that Margio is turned to be an anti-hero, anti-adept, who goes down the anti-path (anti-tarikat). The post-human Margio is back to the animal nature of its far ancestors.

The chaos in our souls is the tiger. This warning of Eka Kurniawan is a masterpiece of new Indonesian literature, undoubtedly.

\section{The Sea and the Volcano - remythologization of the Javanese spiritual duality}

The opposite process of the deconstruction is the conservation the tradition by keeping it up-dated and up-graded in order to fit the nowadays needs and aspirations. The modern Indonesian writer Budi Sardjono (born in 1953) managed to publish successfully a number of novels, main characters of which are the specific Javanese deities of the Sea and the Volcano in his bestseller "The Queen of the Southern Sea" (Sang Nyai, 2011).

European Romantics of the first part of the XIX century (like Ernst Theodor Amadeus Hoffmann) used the method of duel conception of reality. It seems that Budi Sardjono adopted some Romanism features, like romantic irony and humor, and put his protagonist, journalist Sam, in between the reality and the fantastic realm of Javanese spirits and mighty deities, like Kyai Sapu Jagad and Nyai Roro Kidul. The strong Javanese mysticism (kejawen) aura is preserved in Budi Sardjono's works, which are popular and quite simply written. Addressing the wide audience Budi Sardjono introduces the bizarre world of Javanese beliefs to his readers, and the main pathos of his novels it aimed to save the tradition to the next generations.

The duality of Javanese mysticism roots in general Austronesian myths about the Great Opposites, the sky and the earth, the peak of the mountain and the sea bottom, and also about the sun and the moon, their sacred marriage and close kinship.

The Warden of the Volcano Merapi is represented in multiplied images of all-mighty deity and in some human-like figures, like Kang Petruk. "Laughing man" with "bun of hair tangled on the top of his head" is "tall", has "long nose" and "big belly" (Sardjono, 2011, p. 31). The wayang-alike character helps the protagonist save the inhabitants of the Merapi mountain slopes to escape from the eruption.

A lot of studies are devoted to Semar, Petruk, Gareng, Bagong as main punokawan characters in Javanese wayang. The change of their names in some sources (in cerita Panji texts they are called Persanta, Jerude, Punta, Cemuris etc.) does not change the main idea, that the punokawan figures are the all mighty deities of ancient truly agrarian times of Java. Semar is no one but Batara Ismaya, the big brother of Batara Guru (the Divine Teacher, or Shiva - M.F.). Semar and his clown company descended to the earth to guide the royal princes and to save 
them from the harm, but sometimes they act silly and make everyone laugh at their comic behavior. Being close to common people, Semar is responsible for the whole Java land, he is its spirit and its emblem (Kresna, 2012, pp.55, 60-61).

Hosts of sakti power, Semar and other punokawan are related to the places of its concentration - the mountains and the volcanoes. Volcano can display the whole Universe - the Upper world at its peak and the Underworld in its craters. Tantu Panggelaran, the mythological Javanese chronic, mention the God Brahma striking the iron in the crater of volcano, named after him - Bromo (Parnickel, 1973, p.270). Folk culture enabled the Indian God to be the magician and the blacksmith. Sometimes this deity is called after the second popular punokawan Petruk.

His honorific name "Kyai Sapu Jagad", used in the novel of Budi Sardjono, etymologically comes from the words "Great Master", "Broom" and "Universe". Sweeping the world, the Master keeps it clean and in balance. Also he is addressed as Sunan Gunung Lawu, or "Lord of the Lawu Mountain", another sacred peak in Central Java.

The plurality of the same object is the common case in animism. Nature is not the opposite for the humans - on the contrary, they are isomorphic and can be mutually transformed and manifest in each other. The human character of Sam in Budi Sardjono's novel gets close to the divine and to the strange metamorphosis of two main Javanese deities, Nyai Roro Kidul and Petruk. The last one is represented in the novel like the adviser and the guardian of the Merapi crater.

The journey to Kang Petruk's place of habitat - the cave - lies through the forest. Actually, Sam arrives in the old-times Yogyakarta city. Crossing over space and time repeats the traditional hero's path to the other kingdom (read: other world). The Cave of Petruk is the boiling crater of Merapi, and its master feeds his oven with human bodies to keep the fire in balance. The phantasmagoric scene is also the reminder, that the blacksmiths (and first of all, the smiths of keris, Javanese sacred daggers) were considered in many cultures like the devil's servants. However, in Java the power over the fire and the metal means nothing bad - on the contrary, the blacksmiths are closer to the divine; they can obtain the sakti power and other magic skills. The underworld blacksmith Kyai Petruk is keeping the harmony and the balance of the Universe, as his close friend and alliance Nyai Roro Kidul does. This honorific name is not the only one. Ricklefs mentioned a dozen of them: Retna Dewati, Prabu Roro Rat Jawi, Sang Retno, Sang Dewi, Kajeng Nyai Roro Kidul, Gusti Ratu Kidul etc. (Ricklefs pp.64-74).

The name used in the novel is Nyai Roro Kidul. Nyai matches Kyai and makes the opposite of Male and Female. The Female (Roro) Master, the Ruler of the South $(K i d u l)$ has a cult which is still thriving in nowadays Java. Myths of her origin often reveal the story of a skin disease, which made the royal girl throw herself from the cliff into the sea. She was crowned the queen of the South Sea (in Java it means the Indian Ocean - M.F.) by its inhabitants, the spirits and magic underwater creatures. The skin disease is the mark of her snake-like nature and the rudiment of the former hypothetically existed snake cult (she can be also referred as Nagini from Indian origin). Her manifestation as Nyi Blorong is a local image of a "mermaid" with big snake tail. Snake nature helps her to keep a sharp eye on all the gold and treasures hidden in the earth (Jordan, 1997). 
Chthonic image of the goddess links with the female, cold archetype of the ocean, the symbol of the cosmic chaos. The water has a double nature as a source of life and death at the same time. It is no coincidence that the Javanese think of the danger not because of the volcano, but the ocean. They believe that the drowned and the victims of a shipwreck are taken as servants of Nyai to the sea bottom. In order to prevent the anger of the goddess, ceremonies and rituals like labuh and larung are taken place, the fleet of offerings for Nyai's good will (Wessing, 1997, p.106).

Not alike Dewi Durga, Nyai Roro Kidul does not have her wayang figure or mask, but is commonly represented as a wise and beautiful lady of ripe age, wearing gorgeous Javanese dress of the turquoise color. Budi Sardjono creates her image according to these beliefs. He also did not forget about the sacred marriage: not a secret that science Islam came to Java, the sea goddess is told to become a lover of all the sultans of Mataram kingdom (XVII-XIX centuries). The belief is circulating till now: the rulers of Yogyakarta and of Solo (Surakarta) are said to have a relation with her (Pigeud, 1964, p.211).

Despite the conversion to Islam, the Island of Java keeps the belief in the sea and volcano deities. The reflection of the old dual image 'Mountain-Sea' tracks back to the XIX century, to the 'records' of Goddess of the Sea and Master of the Mountain royal meetings. There is also told that then the Master is out of Java, the role of the warden overcomes to the sea goddess. This superstition is in harmony with the main principles of the Javanese dualism (Geertzp, 1960, p.23).

The main figure of the Budi Sardjono's novel, Nyai Roro Kidul herself (split in her many manifestations - the novel characters), is proofed to be a nice living myth and another emblem of the Javanese culture. The modern novel demonstrates the actuality of the basic archetypes for the Javanese, and, of course, for the other ethnics of Indonesia. The motivation for the creating such characters, as the ancient deities, lies in the concept of the retained balance of the archaic culture as much as in the conscious chose of stylization. The archaic patterns, the myths and the original images are also known as archetypes of the human psyche. The "eternal presence" of such archetypes as Fire, Water, Male, Female etc. made the contemporary book worthy and interesting. Appeal to the constant opposites and balance in our lives helps to revive and to rehabilitate the well-known symbols of Java and to strengthen the all-Indonesian cultural identity. Budi Sardjono tells about the new search of the roots and the new attempt to adopt the past.

\section{Conclusion}

Chosen novels are representing three basic concepts of Indonesian culture, coded in symbols. There are three big worlds: the sakti-ful Heaven or Mountain peak, the Earth, full of heroes, antagonists, wild beasts and mediators - shamans, the Underworld, like the underground craters and caves and the sea bottom, full of chthonic creatures. The enrichment of main mythological symbols happened in the 'medieval' (according to European periodization - M.F.) times, when the strong wave of Islam overcame the old religions of Hinduism and Buddhism and its fusion with the local animistic beliefs. New paradigm brought the Sufi 
connotations to the old images, turning them into the symbols with additional meanings.

The Europeanization gave new perspectives for the literary proses, but only in last few decades the Indonesian authors started to search for the foundation of their literature not abroad, but in the very country. 'Back-to-basics' concept, NeoTraditionalism, recalled ancient patterns and plots of traditional cerita. Some of the new Indonesian writers reviewed the main images and showed their ambiguities to the reading audience by deconstructing the core principles of the traditional symbols. Animism is a powerful source of symbol creating, and the very process is well known for Indonesian oral tradition and the modern literature. The few chosen symbols of animistic genesis drive the literature forward and review the myth in different ways. Like Sea, Volcano, Tiger, Gods and spirits, Myth is the greatest symbol of his own.

\section{References}

Braginsky, V.I. (2001). The comparative study of traditional Asian literatures: From reflective traditionalism to neo-traditionalism. London: Routlege.

Eliade, M. S. (2014). Archaic techniques of ecstasy. Russian: (n.p.). (Original work published 1951).

Frazer, T. M. (1960). Rusembilan: A Malay fishing village in southern Thailand. Ithaca, NY: Cornell University Press.

Geertz, C. A. (1960). The religion of Java. London: Free Press of Glencoe.

Jordaan, R. E. (1997). The mystery of Nyai Lara Kidul, the goddess of the south ocean. Archipel, 28, $99 \quad-116 . \quad$ Retrieved from www.persee.fr/docAsPDF/arch_00448613_1984_num_28_1_1921.pdf

Kresna, A. (2012). Punakawan: Simbol kerendahan hati orang $\bar{J} a \bar{w} a$. Yogyakarta: Narasi.

Kurniawan, E. (2004). Lelaki harimau. Jakarta: PT Gramedia Pustaka Utama.

Lévi-Strauss, C. T. (2008). The savage mind. Russian: (n.p.). (Original work published 1962).

Lubis, M. (1975). Harimau! Harimau! Jakarta: Pustaka Jaya.

Parnickel, B. (1973). The tale of sang boma. Moscow: Nauka.

Pigeaud, T. G. (1964). Java in the $14^{\text {th }}$ century: A study in the cultural history. The Hague: Nijhoff.

Ricklefs, M. C. (1974). Jogjakarta under Sultan Mangkubumi 1749-1792: A history of the division of Java. London: Oxford University Press.

Sardjono, B. (2011). Sang Nyai: Wajah cantik sarat misteri dan karisma Roro Kidul. Yogyakarta: DIVA Press

Schimmel, A. (2012). Mystical dimensions of Islam. (Original work published 1975). Retrieved from http://www.fatuma.net/text/schimmel.pdf

Skeat, W. W. (1900). An introduction to the folklore \& popular religion of the Malay peninsular. New York: Barnes \& Noble, Inc.

Wessing, R. (1997). Nyai Roro Kidul in puger: Local applications of a myth. Archipel, 53, 97-120. Retrieved from www.persee.fr/docAsPDF/arch_00448613_1997_num_53_1_3395.pdf 